\title{
Poetry Appreciation and Paraphrasing Skills of Grade 9 Students
}

\author{
Jane Catherine A. Tobis ${ }^{1}$ and Chona G. Mascuñana ${ }^{2}$ \\ ${ }^{1}$ Isabela National High School, Negros Occidental, Philippines \\ 2University of Negros Occidental-Recoletos, Bacolod City, Philippines
}

\begin{abstract}
Article history
Submitted: 24 October 2020

Revised: 10 November 2020

Accepted: 12 November 2020

\section{Keywords}

Language Education

Poetry Appreciation

Paraphrasing Skills

Grade 9 Students

Descriptive-Correlational

Negros Occidental
\end{abstract}

Introduction. Among all the literary pieces used in English language teaching, poetry has always been regarded as an interesting and challenging literature genre used in English language teaching. Researchers that explored the appreciation of poetry and the factors that affect its approach had different points of view; however, they certainly agreed on the universal concern of research on the difficulty and lack of enthusiasm in dealing with poetry. Accordingly, recent neuroscientific research commenced using poetry in paraphrasing since both complement one another in language teaching. As a literary product, poetry requires a high analysis skill for adequate comprehension, while paraphrasing involves extensively analyzing ideas and forming new borrowed personal interpretation. Hence, this study aimed to see the relationship between students' degree of poetry appreciation and paraphrasing skills.

Methods. This quantitative study used descriptive-comparative and correlational research design to determine, compare, and contrast poetry appreciation and paraphrasing skills of Grade 9 students of Isabela National High School during the School Year 2019-2020. 256 respondents were identified using stratified random sampling. The data were generated using a researcher-made survey and test questionnaire. Accordingly, students were asked to read and assess how much they appreciate poetry through a five-point Likert scale and to effectively paraphrase a poem, which was evaluated using a rubric based on the guidelines of a successful paraphrase. Data analysis was done using Mean, Standard Deviation, frequency count, percentage distribution, Analysis of Variance (ANOVA), KruskalWallis, and Spearman rank correlation.

Results. The findings of the study, when taken as a whole, indicated a high degree of poetry appreciation and an average level of paraphrasing skills among Grade 9 students. When grouped according to class section, a significant difference exists between students' poetry appreciation and paraphrasing skills, where the Special Science Program students performed better on given tasks compared to other students from the regular classes. Hence, there is a significant relationship between students' poetry appreciation and paraphrasing skills.

Conclusion. Developing the appreciation of poetry and paraphrasing skills among English language learners could best equip them to be more proficient in the higher levels of language learning. Students' constant exposure to vast literary pieces used in English language teaching enables them to familiarize themselves with the nature of various literary pieces, such as poems, and the complexity of language used therein. The inclusion of these literary pieces in language learning creates the foundation for students' appreciation and comprehension of these literary works in general. Accordingly, the development of rich vocabulary and decoding skills must be addressed in class to enhance students' ability to express themselves adequately. This could be made possible through constant practice in class, even in simple answering questions during class discussions. Students must be encouraged to restate ideas based on their understanding of the lesson or selection discussed without negatively judging their responses. This would eventually pave the way to a more comfortable and enjoyable learning environment. Hence, students' degree of poetry appreciation notably influences their ability to paraphrase poems even with figuratively complex languages. Activities that promote such skills must be appropriately utilized in a language class to encourage 
students' engagement and comprehension. Finally, the materials to be used must also be specific to their degree of poetry appreciation and level of paraphrasing skills to ensure a step by step process of development.

Practical Value of the Paper. The study significantly juxtaposes with few studies of poetry appreciation and the use of paraphrasing as a comprehension tool. Specifically, the findings of the study provided teachers with a baseline of students' degree of poetry appreciation and level of paraphrasing skills, through which they will be able to create effective instructional materials to augment the existing gap in the teaching and learning of poetry. Moreover, future researchers can integrate the results of this study for contradiction or affirmation of topics alike.

\section{References}

Cabasan, H. C. (2014). Appreciating Poetry: The Teaching-Learning Analysis. Retrieved from http://uruae.org/ siteadmin/upload/UH0917142.pdf

Daniel, I. O. A. (2013). A critical look at the teacher factor in senior high secondary school students. Poetic appreciation skill development. Theory and practice in language studies, 3(2), 222-222. Retrieved from http:// dx.doi.org/10.4304/tpls.3.2.22232

Dedei, B. C. N. (2013). Research on the Level of Appreciation of the Selected African Poetry at the Secondary School Level.

Hirvela, A., \& Du, Q. (2013). 'Why am I paraphrasing?': Undergraduate ESL writers' engagement with sourcebased academic writing and reading. Journal of English for Academic Purposes, 12(2), 87-98. https://doi. org/10.1016/j.jeap.2012.11.005

Liao, M., \&Tseng, C. (2010). Students' behaviors and views of paraphrasing. Pan-Pacific Association of Applied Linguistics, 14(2), 187-211.

Magulod, G. C. (2018). Innovative learning tasks in enhancing the literary appreciation skills of students. Retrieved from https://us.sage.pub.com/en-us/nam/open-access-at-sage.

Na, C. D., \& Mai, N. X. N. C. (2017). Paraphrasing in Academic Writing: a Case Study of Vietnamese Learners of English. Language Education in Asia, 8 (1). DOI: 10.5746/LEiA/17/V8/I1/A02/Na_Mai.

Pecorari, D. (2014). Plagiarism in second language writing: is it time to close the case? J. Sec Lang. Writ. 30 94-99 https://doi.org/10.1016/j.jslw.2015.08.003.

Randolph, P. T. (2015). Promoting poetry as a productive paradigm for paraphrasing. Retrieved from http://www. catesolnews.org/2015/03/promoting-poetry-productive-paradigm-paraphrasing.

Quagie, J. K. (2012). The Construction of Poetry Teaching in Ghanaian Senior High Schools Core English Language Textbooks, Accra, Ghana Telecom University College.

\section{Correspondence:}

Jane Catherine A. Tobis [cathtobis13@gmail.com]

https://orcid.org/0000-0002-4364-0863 